\title{
FLUVIAL ADJUSTMENTS TO SOIL EROSION AND PLANT COVER CHANGES IN THE CENTRAL SPANISH PYRENEES
}

BY

SANTIAGO BEGUERÍA ${ }^{1,2}$, JUAN I. LÓPEZ-MORENO¹, AMELIA GÓMEZ-

VILLAR $^{3}$, VIRGINIA RUBIO ${ }^{4}$, NOEMÍ LANA-RENAULT ${ }^{1}$ AND JOSÉ M.

GARCÍA-RUIZ1

${ }^{1}$ Instituto Pirenaico de Ecología, CSIC, Campus de Aula Dei, Apartado 202, 50080Zaragoza, Spain.

2 Division Landscape Dynamics, GIS and Hydrology, Faculty of Geosciences, Utrecht University, The Netherlands.

${ }^{3}$ Department of Geography, University of León, Campus de Vegazana, 24071-León, Spain.

${ }^{4}$ Department of Geography, Autonomous University, Cantoblanco, 28049-Madrid, Spain.

Beguería, S., López-Moreno, J.I., Gómez-Villar, A., Rubio, V., Lana-Renault, N. and García-Ruiz, J.M., 2005: Fluvial adjustments to soil erosion and plant cover changes in the Central Spanish Pyrenees. Geografiska Annaler.

\footnotetext{
Abstract

Until the middle of the 20th Century, Pyrenean rivers were characterized by braided channels, unstable sedimentary structures and an almost complete lack of plant cover in the alluvial plain, due to the high sediment yield in hillslopes and the occurrence of frequent and intense flooding. This was probably related to strong
} 
demographic pressures, including the cultivation of steep slopes, frequent fires, deforestation and overgrazing. Depopulation and farmland abandonment resulted in plant recolonization in formerly cultivated areas, causing a decrease in runoff and sediment yield. As a consequence, most Pyrenean rivers tend to reduce the width of the alluvial plain and to replace the braided pattern with an incised, somewhat meandering pattern, involving the construction of new terrace levels and the stabilization of fluvial bars.

Key words: fluvial adjustments, sediment yield, fluvial incision, farmland abandonment, Central Spanish Pyrenees.

\section{Introduction}

The pattern and dynamics of a fluvial channel are strongly governed by the discharge, especially by infrequent flooding, as well as by the volume and grain size distribution of sediments transported by the floods. Each river tends to be in equilibrium with the hydrological and geomorphological dynamics of the surrounding hillslopes, in such a manner that when these dynamics change, the fluvial channel adjusts to the new conditions until a new state of equilibrium is reached (Leopold and Wolman 1957; Schumm 1977; Harvey 1987). Rapid changes occur, for instance, in mine-affected rivers, with aggradation and braiding following an increase in sediment supply, or degradation when supplies became depleted (Knighton1990). Channel changes following check-dams construction in mountain creeks are another example of river adjustments to sediment supply (Lenzi and Comiti 2003). Low-frequency rainstorms can also cause massive sediment input to the fluvial system, resulting in widening, 
straightening and aggradation, whereby a meandering channel can be replaced by a braided one (Harvey 1987).

Most of the basin characteristics are commonly stable over the long term. However, land uses and vegetation cover can change quickly in response to human activity. This is very important, since plant cover is one of the factors that effectively controls runoff and sediment yield (e.g., Thornes 2005). Deforestation and cultivation of steep slopes have been responsible for the instability characterizing most Pyrenean rivers for centuries, leaving braided channels, coarse sediment and almost no riparian cover in the alluvial plains (García-Ruiz and Valero-Garcés 1998). Nevertheless, a generalized trend towards stabilisation and colonisation with shrubs and trees has been observed in recent decades, suggesting a history of fluvial adjustments to decreases in discharge and sediment transport. This study examines the consequences of such changes on the fluvial dynamics, particularly the adjustments linked to farmland abandonment and reforestation.

\section{Study area}

The study was carried out in the Central Spanish Pyrenees, principally in the Eocene Flysch Sector (Fig. 1), where extensive plant cover changes have historically occurred, extending into the 20th Century. Sandstones and marls alternate in thin beds that are strongly folded and faulted. Altitude ranges from 600 to $2200 \mathrm{~m}$, and the relief is characteristically smooth, with straight hillslopes, covered by colluvial deposits (García-Ruiz and Puigdefábregas 1982).

The weak resistance of the bedrock tends to trigger erosion processes, such as the active headwaters of ravines, sheet wash in most deforested areas (García-Ruiz and Puigdefábregas 1982), and shallow landslides (Lorente et al 2002). 
The climate is sub-mediterranean, and somewhat continental. Average annual precipitation ranges from $700 \mathrm{~mm}$ (in the southern part of the study area) to about 2000 $\mathrm{mm}$ in the divides. The moist season runs from November to April, with a short, dry season in summer. The most intense rainstorms occur in autumn.

Plant cover has been strongly impacted by human activity. Historically, cultivated areas were located below $1600 \mathrm{~m}$ a.s.l. in the valley bottoms, perched flats, and on the steep, south-facing hillslopes, which were cultivated even under shifting agricultural systems. The forests have remained relatively well preserved on the north facing slopes and indeed everywhere between 1600-1800 m. The upper divides are covered by the grasslands of the sub-alpine belt.

During the 20th Century, most cultivated fields were abandoned, except in the valley bottoms. Abandoned fields, representing about $25 \%$ of the total area, have been affected by a natural process of plant recolonization (mainly dense shrub communities, but also woodland in the most favourable locations) or have been reforested for land reclamation and to reduce reservoir siltation (Ortigosa et al 1990). Moreover, the use of fire for land management has been abandoned in the last decades. In addition, the subalpine belt is being slowly recolonized by trees as the livestock pressures decrease, amounting to an $80 \%$ reduction in the sheep population. For this reason, VicenteSerrano et al. (2005) have identified a positive trend in the temporal evolution of the vegetation biomass in the Central Spanish Pyrenees, using the annual integrated Normalized Difference Vegetation Index (NDVI). These authors have demonstrated that abandoned fields present the greatest NDVI increase, followed by shrub cover areas and forests (Photo 1). 


\section{Materials and methods}

Information on runoff and sediment yield under different land uses was taken from the "Aísa Valley" Experimental Station (Fig. 1) using eight erosion plots permitting runoff generation and soil erosion comparison from dense shrub cover, cereal crops in steep slopes, abandoned fields, and shifting agriculture, among other areas. The plots were $30 \mathrm{~m}^{2}$ in size, with a $25 \%$ slope.

Basin-scale information on discharge and sediment transport was collected from two different environments: (i) The Arnás catchment (284 ha), which was cultivated for cereals and abandoned about 40 years ago, is now mostly covered with shrubs. (ii) The San Salvador catchment (90 ha), which corresponds to a densely forest-covered, nondisturbed area (Fig. 1). Both catchments are located at similar altitudes (900-1400 m a.s.1.), while bedrock (flysch), topography, and precipitation features are the same at any temporal scale. Discharge, suspended sediment and solutes (measured every 5 minutes) and bed load (weighted in a sediment trap after each rainstorm event) allowed us to estimate a provisional sediment balance.

Remote sensing and geographical information systems were used to assess sediment sources on a larger scale (basins greater than $1000 \mathrm{~km}^{2}$ ). Information was also available on reservoir siltation rates for some Pyrenean reservoirs. The effects of land cover and climate changes on water resources throughout the Central Spanish Pyrenees were also analysed (Beguería et al 2003). Geomorphic mapping of the evolution of alluvial plains and alluvial fans was made by aerial photography interpretation from $1928(1: 18,000), 1956(1: 33,000), 1977(1: 25,000), 1981(1: 18,000)$ and 2002 $(1: 18,000)$. In the case of the Cinca River alluvial plain two sets of aerial photographs were compared, from July 1929 and July 1981. After delineating the maps, control 
points were fixed and the 1929 map was rectified to the 1981 map using a polynomial transformation to correct the differences in the image projections.

\section{Evidence of streamflow and sediment yield decrease}

Different sources of information indicate that streamflow and sediment yield have been decreasing in the Central Spanish Pyrenees since the middle of the 20th Century. The results obtained from the "Aísa Valley" Experimental Station do not correspond to true erosion rates because of the conditions in which the information was obtained (relatively small closed plots), although they serve for comparative purposes and to emphasize the main hydromorphological consequences of different land uses (García-Ruiz et al 1995 and 2004). These results suggest that:

(i) Cereal cultivation on steep slopes yielded the highest rates of overland flow and sediment yield, particularly in the case of shifting agriculture. Erosion rates are about $1.5 \mathrm{t} \mathrm{ha}^{-1} \mathrm{yr}^{-1}$.

(ii) Farmland abandonment represented a clear decrease in water and sediment yield, due to relatively rapid plant colonization, representing an erosion rate of $0.5 \mathrm{tha}^{-1}$ $\mathrm{yr}^{-1}$. Nevertheless, as plots abandoned after shifting agriculture were left with a disturbed soil, low in organic matter and nutrient contents, the beneficial effects of farmland abandonment were smaller.

(iii) A dense shrub cover was able to retain most of the precipitation, reducing erosion rates to almost zero (about $0.1 \mathrm{t} \mathrm{ha}^{-1} \mathrm{yr}^{-1}$ ). Meadows behaved in a similar way.

As a reference, the average runoff coefficient was twofold under shifting agriculture than under the abandoned agriculture plot, and five times higher than that of dense shrub cover. Regarding soil erosion, the dense shrub cover recorded 14 times less 
soil erosion than shifting agriculture and 4 times less than the abandoned agriculture plot (García-Ruiz et al 1995).

These findings indicate that, over the last centuries, hillslopes have contributed to a rapid hydrological response during rainstorm events. The abandonment of most cultivated fields, now occupied by dense shrubs and cutting meadows, might have reduced the supply of both water and sediment toward these channels. Photo 1 is a good example of land use changes in the Central Spanish Pyrenees over the last decades. In Photo 1A (1957) most of the hillslopes are occupied by cultivated fields (mainly wheat and barley) in steep slopes, with small shrub areas. In photo 1B (2002) the whole cultivated area has been abandoned and colonized with pine forest and dense shrubs.

These results take on a greater significance when weighed with information from the Arnás and San Salvador experimental catchments. For example, Fig. 2 displays the hydrograph corresponding to the same rainfall event, occurred at the beginning of March, 2001 at both catchments. The rapid response of the Arnás catchment, with its higher peak flow, was likely due to the presence of eroded areas close to the main channel, a legacy from decades of farming and grazing (García-Ruiz et al 2005). On the other hand, San Salvador presented a typical forest cover showing a delayed hydrograph compared to Arnás. Both the rising and the falling limbs of the hydrograph are smoother due to both interception and infiltration. The sediment balance for the year 2000 (Fig. 3) confirms the different manners of flow circulation within the catchment: In the case of Arnás, sediment transport is dominated by suspended sediment, followed by solutes and bed load. This suggests the importance of splash and sheet wash erosion, and therefore, the predominance of overland flow. In San Salvador most sediment output is carried out as solutes, with a low proportion of suspended sediment, indicating the importance of infiltration. The occurrence of bed load records in Arnás is yet further evidence of 
torrentiality as well as a high-energy environment resulting from lower plant cover density. A recent evaluation of the role of bed load in the sediment balance of the Arnás catchment increases its proportion to up $20 \%$ of the total (Regüés et al 2004)

When this problem was studied at a large-scale basin, Beguería et al (2003) identified a decrease in streamflow in the Central Spanish Pyrenees, regardless of climatic oscillations, during the year 1945 to 1995. By using regional, normalized series of precipitation, temperature and discharge, it was evident that the relationships between regional precipitation and discharge changed throughout the study period. The precipitation index was lower than the discharge index between 1945 and 1970, and higher after 1970. This suggests that there was a progressive decrease in runoff yield for a given precipitation. The difference between the expected trends in discharge (based on climate) and the actual discharge implies that a non-climatic, time-dependent factor governed the decrease in discharge. The only explanation is the general expansion of shrubs and forests in the old cultivated areas, with increasing evapotranspiration (including interception). This is the same argument used by López-Moreno et al (2004) to explain the decreasing number of floods detected in most Pyrenean rivers, even though the most intense rainstorms did not reveal any trend during the last 50 years. Similarly, the decreasing sedimentation rate observed in large reservoirs of the Pyrenees in recent decades (Valero-Garcés et al 1999) has been taken as a proof of decreasing torrentiality as well as of shrinking sediment sources (Beguería 2005).

\section{Channel adjustments}

Results obtained at different scales all point in the same direction: human activity precipitated a noticeable increase in sediment yield and an enlargement of sediment sources. How did alluvial plains evolve historically and what are the current 
patterns? Much evidences centers on the historical torrentiality of Pyrenean rivers. Aerial photographs from the beginning of the 20th Century revealed the dominance of unstable channels. For instance, the Cinca River, one of the most important tributaries of the Ebro River, was characterized in 1929 by a wide, braided alluvial plain between Escalona and Aínsa (Fig. 4), and by a general lack of well colonized bars. Most likely sediment sources were very active by that time and the alluvial plain was renewed continuously, the river having a great capacity to carry sediment. Small areas of shrubs and trees were indeed very sparse, suggesting that the Cinca River was subject to frequent flooding, changes in channel course, destruction of previous sedimentary structures and construction of new ones. Bars behaved as sediment stocks, renewing at a very rapid rate.

By 1981 the most active areas were confined to small point bars upstream of Escalona and near the mouth of the Ara River. In the rest of the channel stretch, a remarkable trend toward plant colonization was observed. Trees and shrubs occupied most of the alluvial plain: Table 1 shows the differences in plant cover characteristics between both dates. In 1929, the area occupied by bare young bars represented $69.6 \%$ of the alluvial plain, whereas by 1981 it had decreased to $31.4 \%$. Old bars with trees and shrubs were 11.1 and $31.0 \%$ respectively. Compared with the 1929 map, the total sinuosity (kilometres of channels per kilometre of river bed) had changed from 3.33 to $3.02 \mathrm{~km} \mathrm{~km}^{-1}$, and the length of the active channels had been reduced from 43.2 to 39.3 $\mathrm{km}$. Comparisons are not possible after 1981 due to the construction of lateral dykes to prevent channel divagation and flooding in recently urbanized areas. In addition, new sections of gravel mining now occupy the alluvial plain, disturbing the natural river dynamics. This same evolution was reported by Rubio and Hernández (1990) for the neighbouring Ara River. 
In torrential rivers (Ijuez and Aurín) of medium size (around $50 \mathrm{~km}^{2}$ ), a comparison of different aerial photographs (from 1956 to 2002) revealed increasing plant colonization of the alluvial bed. Thus, a $20.2 \%$ reduction of the area covered by coarse sediments was found in the Ijuez basin. Coarse sediment still occupies a large part of the valley bottom, but there are no signs of sediment renewal. Both the Ijuez and Aurín rivers are subject to a process of incision (up to $2 \mathrm{~m}$ ), leaving small and recent terrace levels. The old braided pattern has been replaced by a confined, somewhat meandering channel. These new terrace levels are easily colonized by vegetation, since they are increasingly above the average flooding level. As a consequence, willows and other water-exigent plants have been displaced by those of Mediterranean origin, including Buxus sempervirens and Pinus laricio, since the water table is deeper and such plants are resistant to strong hydric and thermic stress. These changes coincide with a general reforestation of pines in both catchments (1012 ha in the Ijuez Valley and 870 ha in the Aurín Valley, mainly between 1955 and 1965), after the abandonment of both the farmed areas and the villages. García-Ruiz and Ortigosa (1988) studied the geomorphic effects of reforestations by comparing ( $\%$ of stones and fine material on the channel surface, $\%$ of plant cover, prevailing geomorphic processes at the adjacent river banks) certain geomorphic-related features in channels from reforested and nonreforested catchments. Channels in reforested catchments were characterized by a higher percentage of plant cover and fine sediment, whereas in non-reforested catchments bare rock and gravels occupied most of the channel. Moreover, the banks of reforested catchments also contained a greater plant cover density and a higher proportion of non-eroded areas, as well as the lowest proportion of severe sheet wash erosion. 
Recent incision was also evident in small catchments, where the shrinking of old sediment sources forces the ravine to erode its own channels. Thus, in the case of the Arnás experimental catchment, most of the hillslopes served as sediment sources 40 years ago, whereas currently sediment is supplied principally by the channel and neighbouring areas. This is due to recent disconnections within the catchments related to farmland abandonment and plant recolonization (Beguería 2005).

A similar trend was observed in the evolution of alluvial fans in the Pyrenees. Around the middle of the 20th Century most of the large alluvial fans at the Ribera de Biescas (Oliván, Escuer and Orós fans) were partially active (Gómez-Villar and García Ruiz 2000). As an example, Fig. 5 shows that the Escuer fan had different sectors according to their degree of activity: one part was cultivated, another had reduced its activity and was colonized by trees, willows and shrubs, and finally yet another was still active, directly affected by frequent flooding, given the absence of plant cover. Of the three alluvial fans, that of Escuer had a remarkably unstable sector: $29.6 \%$ of the total, whereas Orós exhibited 9.2\% and Oliván 9.8\% (Gómez-Villar 1996). Twenty years later braided patterns had disappeared, replaced by a confined channel incised several metres into the fan deposit (particularly at the fan apex). Furthermore, the most active area had been reduced to a narrow strip along one border of the fan. In the case of the Escuer fan the active area was reduced to $2.7 \%$ of the total fan area (Gómez-Villar 1996). It is important to note that after 1950 all the cultivated areas in the Escuer, Orós and Oliván basins were abandoned and replaced by pine reforestations. A few checkdams were later built in the lower stretch of the ravines, immediately upstream of the fan apex, to reduce the sediment supply to these alluvial fans. At present, only extreme pluviometric events can result in an exceptional flood, carrying large volumes of sediment, as it was reported during the Biescas campsite disaster (White et al 1997). 


\section{Discussion and conclusions}

It is well known that the morphology of the alluvial plains (including sinuosity, channel width, gradient and sedimentary structures) adjusts to the basin main features (size, precipitation regimen, types of bedrock, gradients, altitude, plant cover and land uses, among other factors), thereby determining the prevailing geomorphic processes, as well as the volume and grain size distribution of the sediment transported by the floods. Although most of the independent factors do not vary over time, both climate and plant cover lead to changes in sediment and water yield, and for this reason are the responsible for aggradation or incision processes.

Until the middle of the 20th Century, most Pyrenean rivers, especially in the Flysch Sector, were characterized by braided channels with coarse sediment and an almost complete lack of plant cover. The course of the channels, as well as the sedimentary structures, continuously changed position after any flood. This instability was linked to two groups of factors: (i) a bedrock susceptible to shallow landslides with a tendency to yield heterometric sediment toward the rivers; and (ii) intense human activity over centuries, including the frequent use of fire, overgrazing, deforestation and the cultivation of steep slopes, which reactivated erosion processes in these hillslopes (García-Ruiz and Valero-Garcés 1998). Changes in channel morphology after a period of intense human activity has been observed in different environments, particularly in areas of recent European colonization. Thus, Brooks and Brierley (1997) reported extensive widening and bed aggradation in the Bega River, southeast Australia, during the second half of the 19th Century. 
Depopulation, farmland abandonment, and decreases in livestock pressure in Pyrenean areas have encouraged plant recolonization in recent decades. Experimental studies using both plot and catchment scales demonstrated a decreased sediment yield. Sedimentation in reservoirs also confirms that large rivers are transporting decreasing volumees of sediment. This process coincides with a decrease in streamflow regardless of the evolution of precipitation, and can therefore be linked to the expansion of forests and shrubs (Beguería et al 2003).

Are land use and land cover changes the reason for alterations of fluvial channels? Although a direct relationship between the increase of forest and shrub areas, and the channel incision and relative stabilization is difficult to establish, variations in sediment supply following changes in plant cover are the most frequent cause of channel morphology transformation. Thus, in the Roubion River, a tributary of the middle Rhône River, a marked decrease in bedload has been recorded along with an increase in forest cover following the rural depopulation of the 20th Century. The consequences included bed degradation, stabilization of the alluvial plain and channel narrowing (Liébault and Piégay 2001). A similar process has been identified in the Drôme River (Southern Prealps) by Liébault et al (1999). The Malnant River, in the Haute Savoie (French Alps) has also exhibited an incising behaviour in the three decades following reforestation, reducing sediment delivery from hillslopes (Marston et al 2003). As a result, bridges have been undermined, streamside roads are threatened and irrigation diversion structures have become unusable.

All the information compiled at different scales reveals that less water and sediment are yielded to Pyrenean rivers. Nevertheless, only an imbalance between discharge and sediment can explain the change from braided to incised channels. When such disequilibrium exists, this indicates that the decrease in sediment yield has been 
higher than the decrease in runoff, forcing the river to take sediment from its own channel, resulting in incision. This suggests that plant recolonization (reforestation and expansion of shrubs) has a more pronounced effects on sediment than on overland flow.

\section{Acknowledgements}

Support for this research was provided by the following projects: PIRIHEROS (REN2003-08678/HID) and CANOA (CGL2004-04919-C02-01), both funded by CICYT, the Spanish Ministry of Science and Technology, and by RESEL (the Spanish Ministry of the Environment).

Santiago Beguería, Juan I. López-Moreno, Noemí Lana-Renault and José M. GarcíaRuiz, Instituto Pirenaico de Ecología, CSIC, Campus de Aula Dei, Apartado 202, 50080-Zaragoza, Spain.

Santiago Beguería, Division Landscape Dynamics, GIS and Hydrology, Faculty of Geosciences, Utrecht University, The Netherlands.

Amelia Gómez-Villar, Department of Geography, University of León, Campus de Vegazana, 24071-León, Spain.

Virginia Rubio, Department of Geography, Authonomous University, Cantoblanco, 28049-Madrid, Spain .

Corresponding author: José M. García Ruiz: humberto@ipe.csic.es

\section{References}

Beguería, S., 2005: Erosión y fuentes de sedimento en la cuenca del embalse de Yesa (Pirineo Occidental): Ensayo de una metodología basada en teledetección y análisis SIG. Instituto Pirenaico de Ecología.Zaragoza. 158 p.

Beguería, S., López-Moreno, J.I., Lorente, A., Seeger, M. and García-Ruiz J.M., 2003: Assessing the effect of climate oscillations and land use changes on streamflow in the Central Spanish Pyrenees. Ambio, 32: 283-286. 
Brooks, A.P. and Brierley, G.J., 1997: Geomorphic responses of lower Bega River to catchment disturbances, 1851-1926. Geomorphology, 18: 291-304.

García-Ruiz, J.M. and Puigdefábregas, J., 1982: Formas de erosión en el flysch eoceno surpirenaico. Cuadernos de Investigación Geográfica, 8: 85-128.

García-Ruiz, J.M. and Ortigosa, L. 1988: Algunos efectos geomorfológicos de las repoblaciones forestales. Cambios en la dinámica del cauce en pequeñas cuencas del Pirineo Central español. Cuaternario y Geomorfología, 2: 33-41.

García-Ruiz, J.M. and Valero-Garcés, B., 1998: Historical geomorphic processes and human activities in the Central Spanish Pyrenees. Mountain Research and Development, 18: 309-320.

García-Ruiz, J.M., Lasanta, T., Ortigosa, L., Ruiz-Flaño, P., Martí-Bono, C. and González C., 1995: Sediment yield under different land uses in the Spanish Pyrenees. Mountain Research and Development, 15: 229-240.

García-Ruiz, J.M., Lana-Renault, N., Beguería, S., Valero-Garcés, B., Lasanta, T., Arnáez, J., López-Moreno, J.I., Regüés, D. and Martí-Bono, C., 2004: Temporal and spatial interactions of slope and catchment processes in the Central Spanish Pyrenees. IAHS Publ., 288: 21-28.

García-Ruiz, J.M., Arnáez, J., Beguería, S., Martí-Bono, C., Regüés, D., Lana-Renault, $N$. and White, S., 2005: Runoff generation in an intensively disturbed, abandoned farmland catchment, Central Spanish Pyrenees. Catena, 59: 79-92.

Gómez-Villar, A., 1996: Conos de deyección en pequeñas cuencas torrenciales de montaña. Geoforma Ediciones. Logroño. 196 p.

Gómez-Villar, A. and García-Ruiz, J.M., 2000: Surface sediment characteristics and present dynamics in alluvial fans of the Central Spanish Pyrenees. Geomorphology, 34: 127-144.

Harvey, A.M., 1987: Sediment supply to upland streams: Influence on channel adjustment. In: Thorne C.R., Bathurst J.C. and Hey R.D. (eds.): Sediment transport in gravel-bed rivers. Wiley, Chichester, (995 p): 121-150.

Knighton, A.D., 1990: Channel bed adjustments along mine-affected rivers of northeast Tasmania. Geomorphology, 4: 205-219.

Lenzi, M.A. and Comiti, F., 2003: Local scouring and morphological adjustments in steep channels with check-dam sequences. Geomorphology, 55: 97-108.

Liébault, F. and Piégay, H., 2001: Assessment of channel changes due to long term bedload supply decrease, Roubion River, France. Geomorphology, 36:167-186. 
Liébault, F., Clement, P., Piégay, H. and Landon, N.. 1999: Assessment of bedload delivery from tributaries: the Drôme River case (France). Arctic and Alpine Research, 3: 65-79.

Leopold, L.B. and Wolman, M.G., 1957: River channel patterns: braided, meandering and straight. U.S. Geological Survey Professional Paper, 282B: 1-73.

López-Moreno, J.I., Beguería, S. and García-Ruiz, J.M., 2004: Trends in the intensity of floods in the Central Pyrenees [in Spanish, with English abstract]. In: Benito G. and Díez Herrero A. (eds.): Riesgos naturales y antrópicos en Geomorfología. Sociedad Española de Geomorfología, Toledo, (543 p.): 69-78.

Lorente, A., García-Ruiz, J.M., Beguería, S. and Arnáez, J., 2002: Factors explaining the spatial distribution of hillslope debris flows: A case study in the Flysch Sector of the Central Spanish Pyrenees. Mountain Research and Development, 22: 32-39.

Marston, R.A., Bravard, J.P. and Green, T., 2003: Impacts of reforestation and gravel mining on the Mainant River, Haute Savoie, French Alps. Geomorphology, 55: 6574.

Ortigosa, L., García-Ruiz, J.M. and Gil, E., 1990: Land reclamation by reforestation in the Central Pyrenees. Mountain Research and Development, 10: 281-288.

Regués, D., Lana-Renault, N., Martí-Bono, C., Nadal-Romero, E. and García-Ruiz, J.M., 2004: Aplicación de perfilometría en la estimación del transporte en carga de fondo de un torrente de montaña (Cuenca de Arnás, Pirineo Aragonés). In: Benito G. And Díez Herrero A. (eds.): Riesgos naturales y antrópicos en Geomorfología. Sociedad Española de Geomorfología, Toledo, (543 p): 191-200.

Rubio, V. and Hernández, C., 1990: Evolución reciente del cauce del río Ara. Cuadernos de Investigación Geográfica, 16: 99-107.

Schumm, S.A., 1977: The fluvial system. Wiley. New York. 338 p.

Thornes, J.B., 2005: Coupling erosion, vegetation and grazing. Land Degradation and Development, 16: 127-138.

Valero-Garcés, B., Navas, A., Machín, J. and Walling, D., 1999: Sediment sources and siltation in mountain reservoirs: A case study from the Central Spanish Pyrenees. Geomorphology, 28: 23-41.

Vicente-Serrano, S.M., Lasanta, T. and Romo, A., 2005: Analysis of spatial and temporal evolution of vegetation cover in the Spanish Central Pyrenees: Role of human management. Environmental Management, 34 (6): 802-818. 
White, S., García-Ruiz, J.M., Martí-Bono, C., Valero-Garcés, B., Errea, M.P. and Gómez-Villar, A., 1997: The 1996 Biescas campsite disaster in the Central Spanish Pyrenees, and its temporal and spatial context. Hydrological Processes, 11: 1797-1812. 
Table 1. Area (\%) of different environments in the Cinca River alluvial plain

$\begin{array}{lrr} & 1929 & 1981 \\ \text { Old bars with trees and shrubs } & 12.8 & 32.0 \\ \text { Old bars with shrubs } & 4.9 & 9.6 \\ \text { Young bars with shrubs } & 12.7 & 20.7 \\ \text { Bare young bars } & 69.6 & 29.4 \\ \text { Gravel mining } & - & 8.3\end{array}$




\section{FIGURE CAPTIONS}

Fig. 1. Study area. In grey, the Flysch Sector. 1: "Aisa Valley" Experimental station; 2: Arnás catchment; 3: San Salvador catchment; 4: Orós; 5: Oliván; 6: Escuer; 7: Escalona; 8: Aínsa. A: Ijuez River; B: Aurín River.

Fig. 2.Flood hydrographs in the Arnás and San Salvador catchments (March, 3rd 2001).

Fig. 3. Sediment balance in the Arnás and San Salvador catchments (year 2000).

Fig. 4. The Cinca River between Escalona and Aínsa, in 1929 and 1981, from aerial photography interpretation.

Fig. 5. The Escuer alluvial fan in 1956 and 1977. 1: Cultivated area. 2: Area colonized with shrubs and trees. 3: Area with incipient plant colonization. 4: Active channels.

Photo 1. Landscape evolution in the Cenarbe basin, Upper Aragón River Valley, Central Spanish Pyrenees. A: 1957. B: 2002. 


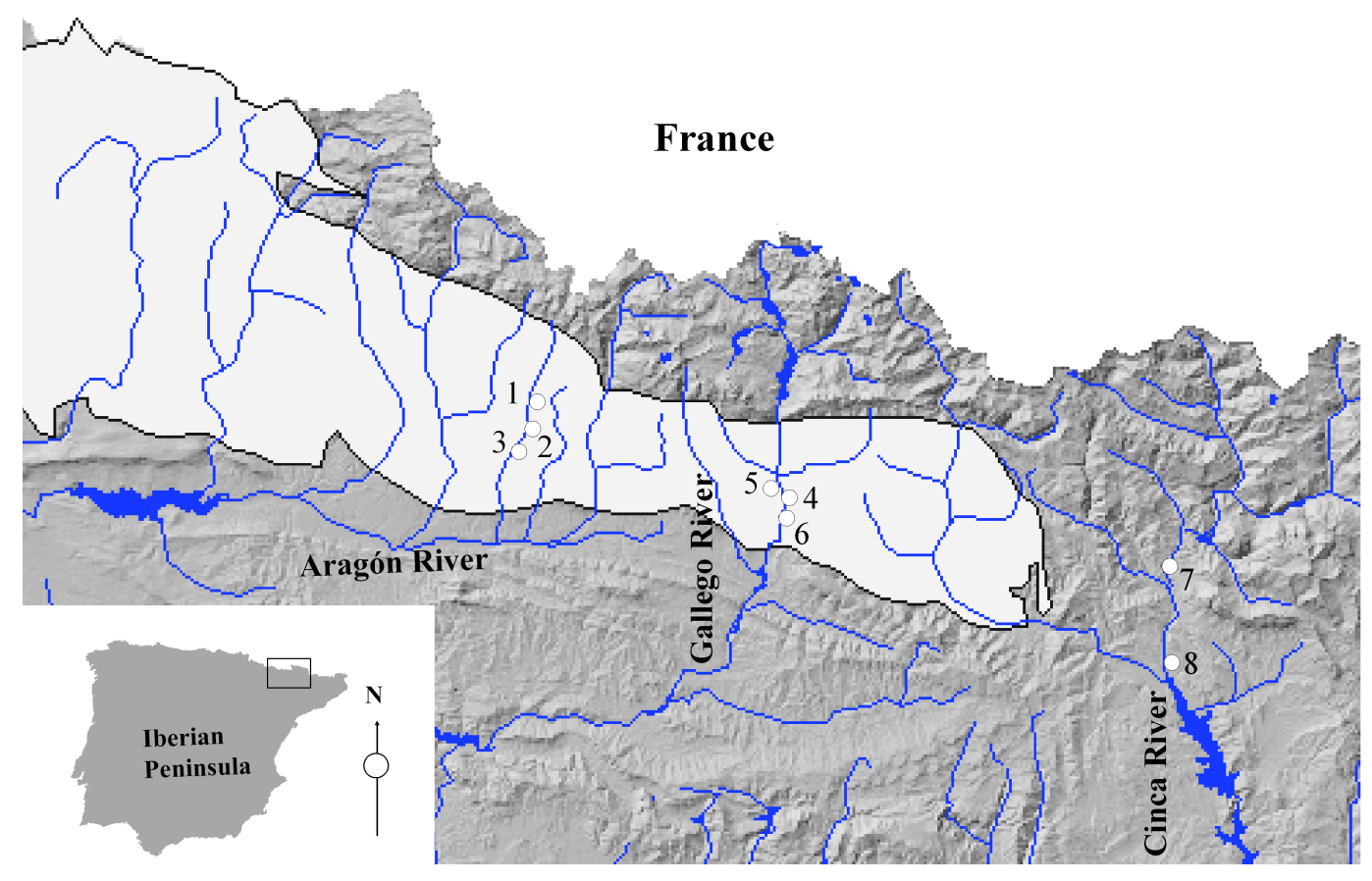

Flysh sector $\quad 20$ km

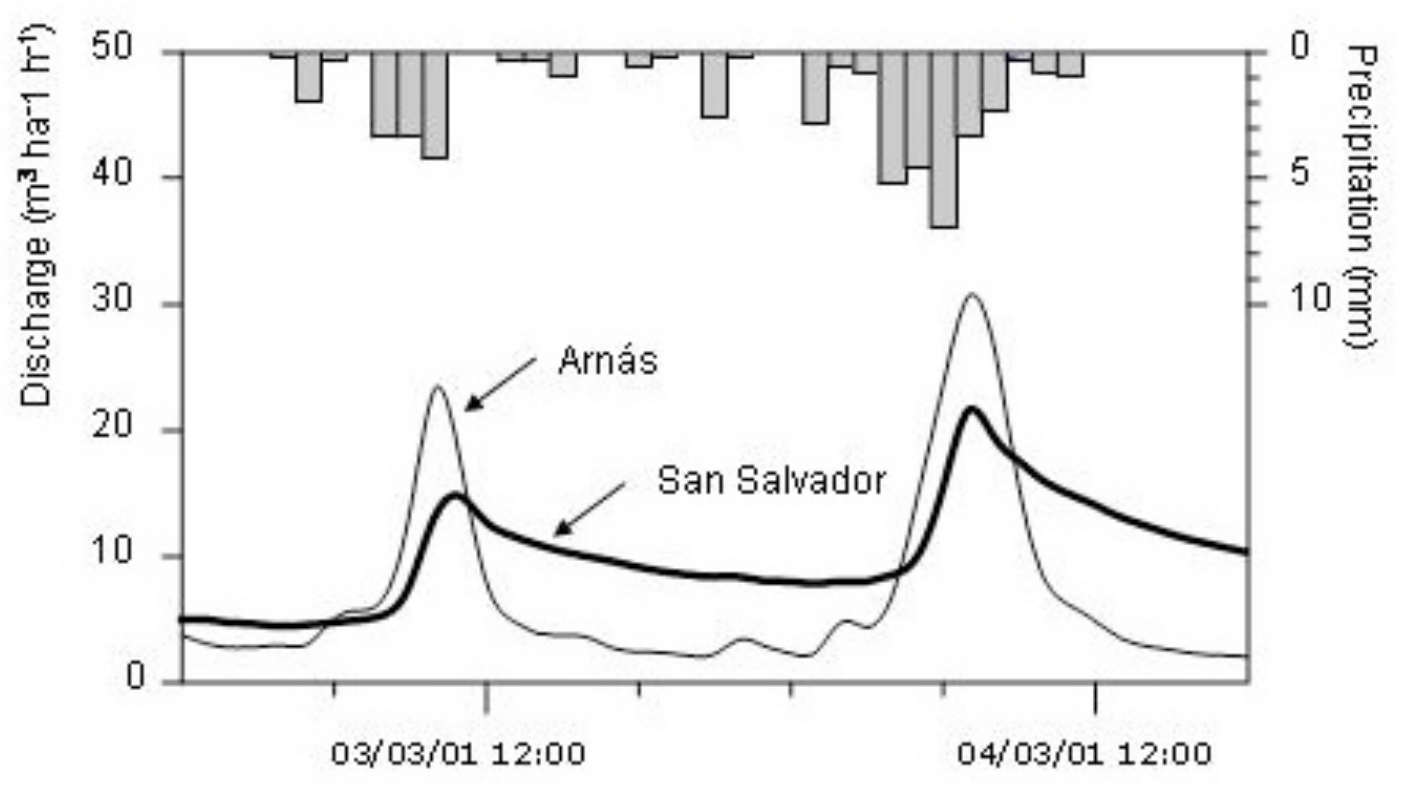


ARNÁS

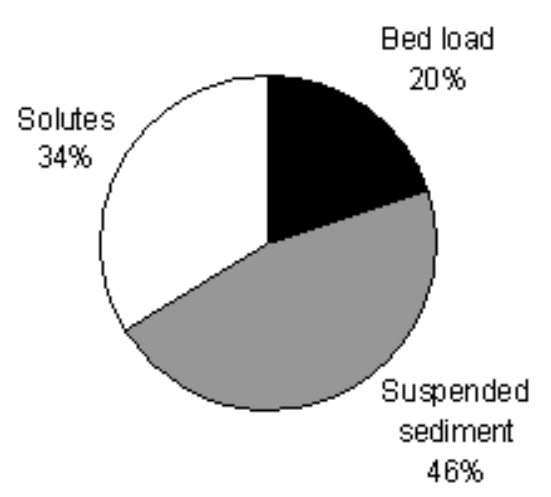

SAN SALVADOR

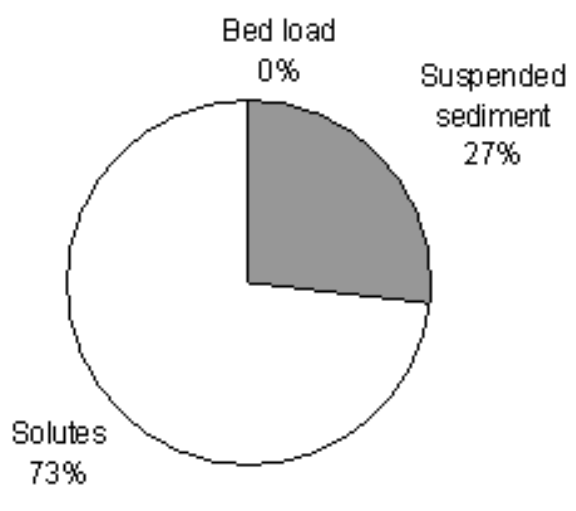



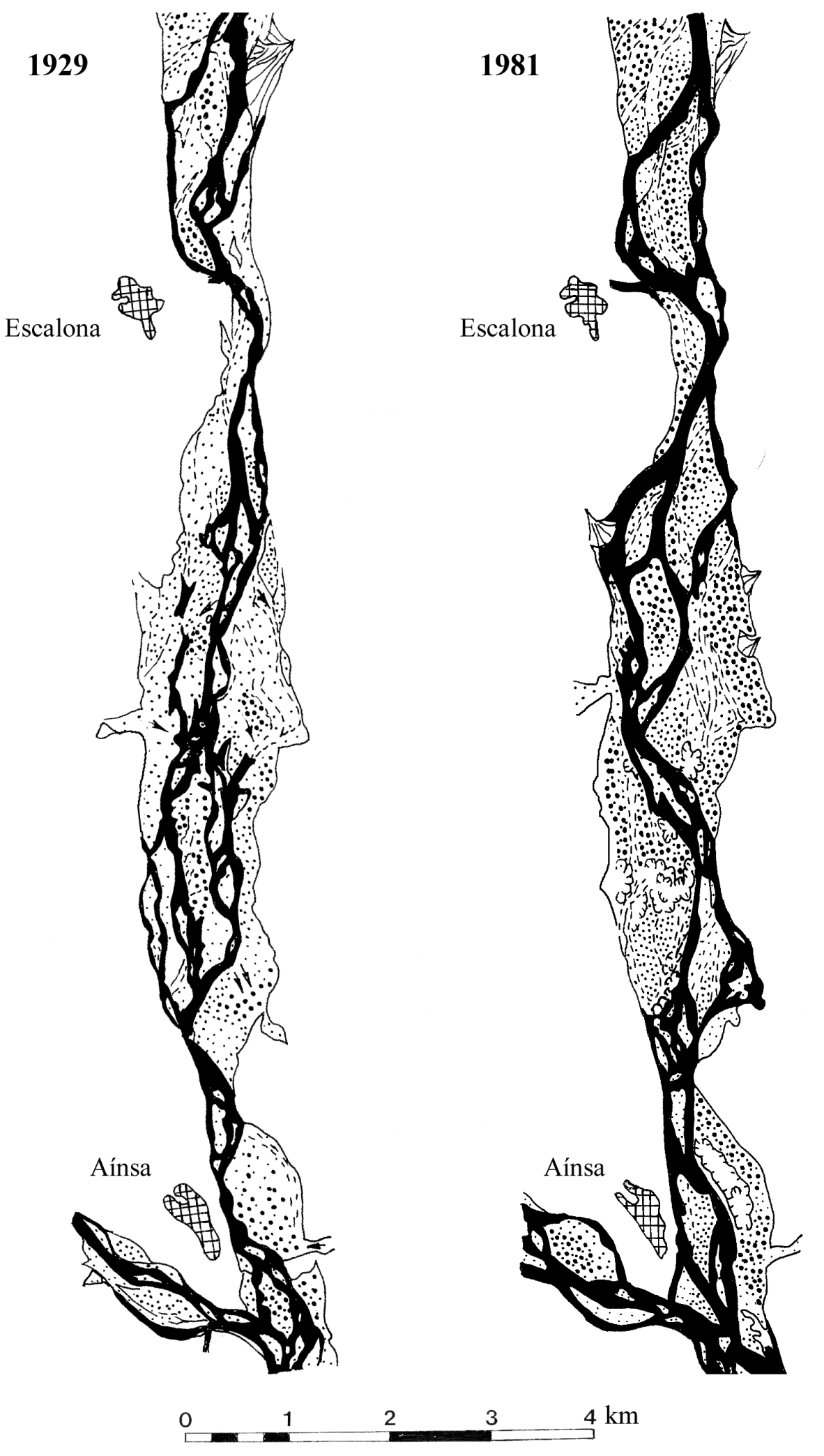

Village

$\therefore$ Bare young bar

$\because$ Old bar with trees and bushes

Young bar with bushes

\begin{tabular}{c}
0 \\
\hdashline
\end{tabular}$:$ Old bar with bushes

Gravel mining 


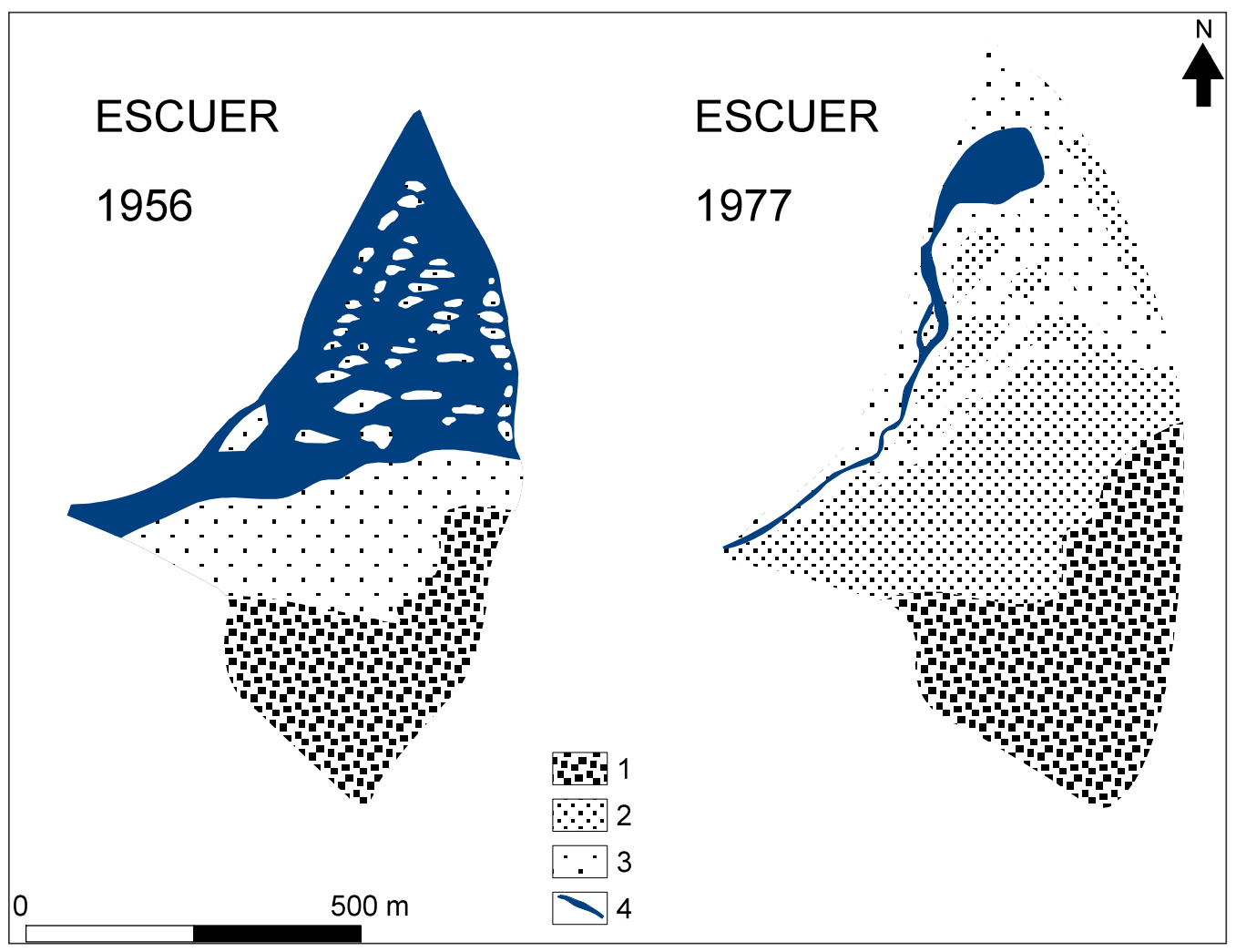

